\title{
ЛИНГВИСТИКА
}

УДК 82.09

UDC 82.09

DOI: $10.17223 / 19986645 / 56 / 1$

\author{
Olga A. Babenko \\ University of Kurdistan Hewlêr (Erbil, Iraq) \\ E-mail: olga.babenko@ukh.edu.krd
}

\section{NABOKOV'S PERFECT PLAY: THE SCREENPLAY LOLITA FROM THE PERSPECTIVE OF THE AUTHOR'S VIEWS ON PLAYWRITING}

Vestnik Tomskogo gosudarstvennogo universiteta. Filologiya - Tomsk State University Journal of Philology. 2018. 56. 5-22. DOI: 10.17223/19986645/56/1

The article researches the last and the least studied dramatic work by Vladimir Nabokov - the screenplay of the novel Lolita - from the perspective of the writer on what constitutes an aesthetically satisfying play. Using Nabokov's methodology and assessing compliance of the screenplay with Nabokov's content-and-form-related criteria of the perfect play, the author concludes that the screenplay contains the full range of his idiosyncratic concepts and artistic devices. The article scrutinizes each of them. Consequently, the research claims that Lolita stands not only as a remarkable play, but also as the culmination of the dramaturgic principles Nabokov employed as a writer and advocated as a theorist of drama.

Keywords: Nabokov, screenplay, theatre, playwriting, poshlust, narration.

\section{Introduction}

Vladimir Nabokov developed his own concept of the perfect play and considered the works of all other authors from this viewpoint; he also created plays with adherence to the principles described in his two works on the art of drama and theatre Playwriting and The Tragedy of Tragedy [1,2]. Referring to the works of playwrights, such as Ibsen, Shaw, Hellman, Steinbeck, and O'Neill, Nabokov insisted that the perfect tragedy had not been created yet, as the action in a play should not develop on the basis of cause-and-effect. Rather, Nabokov thought that the author should freely create his own world without reference to the traditional notion of conflict, as "tragedies based exclusively on the logic of conflict are as untrue to life as an all-pervading class-struggle idea is untrue to history" [2. P. 340]. Nabokov opposed "marble rules of tragic conflict" to "the stormy element of chance", which he considered the source of real dramas and tragedies [Ibidem].

Arguing against the "old iron bars of determinism which have imprisoned the spirit of playwriting", Nabokov claimed that the greatest achievements in poetry, 
prose, painting, and stage direction are characterized by irrationality and possess a "spirit of free will that snaps its rainbow fingers in the face of smug causality" [Ibid. P. 326]. That is why Vladimir Nabokov's artistic method is so close to that of Nikolai Gogol, characterized, as it is, by the incidental and fleeting appearances of personages, who subsequently disappear unknown, defying the commonsensical development of the work of art whereby agents are bridges of causality. Nabokov admired those Gogol's characters, painted on literary canvases not for the realization of the author's ideas, but to manifest the free will of the artist, who was interested in the fleeting beauty of detail. That is why Nabokov's rifles do not fire, why there is no death in The Event, and why the miraculous invention in The Waltz Invention becomes a soap bubble, the lie of a mad thinker. Nabokov often played with the reader's anticipation of cause-and-effect relations and laughed at this confounded expectation.

Nabokov considered detrimental the playwrights' illusion that "life and thus dramatic art picturing life should be based on a steady current of cause and effect driving us towards the ocean of death" [2. P. 337]. Contemplating the driving force of the perfect play, Nabokov brought up examples of several, according to his estimation, brilliant "dream-tragedies", in which "dream-logic, or perhaps better say nightmarelogic, replaces here the elements of dramatic determinism" [Ibid. P. 327], namely Shakespeare's King Lear and Hamlet, as well as Gogol's Government Inspector.

In the commentaries to the most recent Russian collection of Vladimir Nabokov's dramatic works, Andrei Babikov presented a fragment of Nabokov's lecture The Tragedy of Tragedy, which the writer's son Dmitri Nabokov did not include in previous publications and in which the author explained his theory of 'dream-tragedy' in Hamlet [3. P. 635-636]. This fragment suggests that everything that happens in Shakespeare's play is conceived by Nabokov to be a dream of a prince, who had fallen into a deep sleep even before the ship, on which Hamlet was returning home from the university, reached the shore. Nabokov claimed that such an understanding of the play imbues all its incongruities with a "dream-seeing logic, which hides behind the logic of life"1 [Ibid. P. 636]. Nabokov saw the beauty of Hamlet neither in "false ethic references" nor "melodrama", but in a "dramatic spirit of each detail of this dream, in each word of it"4 [Ibid]. Nabokov's contemplation of Hamlet's dream was similar to his notes about Salvator Waltz's dream in the foreword to his own play The Waltz Invention. Analyzing Nabokov's dramatic works, we conclude that all his plays, using the author's terminology, can be defined as 'dream-plays'.

Nabokov questioned himself about the driving force in a dramatic work. $\mathrm{He}$ argued against the presumed impetus of conflict, saying that "the idea of conflict tends to endow life with a logic it never has" [2. P. 340]. He claimed that if we

\footnotetext{
${ }^{1}$ «обретают сновидческую логику, которая кроется за логикой жизни» (here and further translated from Russian by the author; the original citations are provided in footnotes. - O.B.).

2 «фальшивых этических посылках».

3 «мелодраме».

4 «драматическом духе каждой подробности этого сна, каждом слове».
} 
follow only the laws of dramatic conflict and fate, of supernatural justice and inexorable death, tragedy will be limited by its own dogmas and the inescapability of Judgment Day. Nabokov also disputed stringent stage principles, considering it impossible to draw a sharp line between the tragic and the comic, the fatal and the incidental, the causes-effects and caprice of a free will. Nabokov believed that "the higher form of tragedy is the creation of a certain unique pattern of life in which the sorrows and passing of a particular man will follow the rules of his own individuality, not the rules of the theatre as we know them" [2. P. 341].

The only stage convention that Nabokov accepted was the classical principle of the theatre, according to which "the people you see or hear can under no circumstances see or hear you" [1. P. 315]. Nabokov considered alien a so-called 'folk theatre', in which the border between the stage and the audience disappears, and ridiculed Soviet theatrical experiments in engaging the audience. Nabokov compared his conception of theatricality with the philosophy of existence of the world and a man, in compliance with which "in life, too, any attempt at tampering with the world or any attempt by the world to tamper with me is extremely risky business" [Ibid. P. 322]. In rejecting the interaction of stage actors and the audience, Nabokov found his primary dramaturgic axiom and the only acceptable dualism, which is the unsurmountable barrier separating "ego" and "non-ego", by which he meant "self" and "non-self". In Nabokov's opinion, this barrier in the theatre acquired the form of philosophical fatality [Ibid. P. 321].

For Nabokov, violation of the described stage convention was equivalent to the annihilation of the main idea of a drama. Babikov noticed that this thought of Nabokov, which is essential to interpreting the denouement of the novel Invitation to Beheading, can also be found in the second act of The Waltz Invention, as well as in the essay The Art of Literature and Commonsense [3. P. 634]: "It is a combined sensation of having the whole universe entering you and of yourself wholly dissolving in the universe surrounding you. It is the prison wall of the ego suddenly crumbling away with the nonego rushing in from the outside to save the prisoner - who is already dancing in the open" [4. P. 378].

Nabokov named the theatrical audience "the paradox of an invisible world of free spirits" [1. P. 315]. Such an understanding is reflected in Nabokov's play The Event, in which the artist Troshcheykin imagines himself with his wife as actors watched by an audience [5. P. 214]. The audience, in this case, is not real, but an imaginary, theatrical illusion, created by Troscheykin's imagination. Nabokov developed the thought in the lecture Playwriting and earlier realized it in his play The Event. According to this idea, neither a playwright nor an actor should by any means see "a pink collection of familiar faces", which is an audience [1. P. 318]. Otherwise, "the play stops being a play" [Ibidem].

\section{Lolita as the Embodiment of the Artistic Toolware of Nabokov the Playwright}

Nabokov never gave up on the thought of creating "the perfect play" depicting a unique life pattern, a pattern which does not follow conventional theatrical 
rules, but the rules of human individuality [6. P. 14]. It is reasonable to assume that Nabokov meant exactly this when he was considering the production of "the novel in the form of a play" ${ }^{1}$ at the end of the 1960s [Ibid]. The screenplay of Lolita, or a novel in the form of a play, most closely approaches the author's vision of the perfect play. Unsurprisingly, Nabokov's screenplay was used in neither Stanley Kubrick's production (1962) nor Adrian Lyne's film (1997) [7, 8]. Producers, even if they tried, like Kubrick, to catch the whole corpus of Nabokov's narrative and plot devices with a microfilm camera, were unable to do so with insufficient filmmaking, in comparison to writerly, tools. Stanley Kubrick could not find filmmaking equivalents for such Nabokovian devices as defying the reader's expectations, violating cause-andeffect relations, and introducing erotic elements by means of metaphors and shifts in register [6. P. 11]. That is why "only ragged odds and ends" of Nabokov's screenplay were used in Kubrick's film, and what comforted the writer at the time was the understanding that, as he told himself, "nothing had been wasted after all, that my scenario remained intact in its folder, and that one day I might publish it" [9. P. 12-13]. The screenplay of Lolita was published as an independent work in 1974. Its Russian version was published in Andrei Babikov's translation as late as 2010 [10].

\subsection{Lolita as a Dream-Tragedy}

A screenplay adaptation of the novel Lolita co-opted the main insights of Nabokov the playwright, one of which is the conception of the double-world ${ }^{2}$ with its variation, dream-seeing reality, and its corresponding categoriesreality, otherworld and dream. Dreams play the main part in opposing reality and otherworld, as they reify the otherworld, and they have a particular content structure. Moreover, a dream, even if it is not a part of irreality, can serve as a guide to the otherworld.

The otherworld in Nabokov's prose was studied by Alexandrov [12], Barabtarlo [14, 15], Boyd [16, 17], Senderovich \& Shvarts [18] and others; the categories of reality, otherworld and dream were partially analysed by Babikov [19, 20], Frank [13] and Barabtarlo [15, 21]. But holistic study of these categories in Nabokov's dramatic works is still required. The significance of 'dream' in Nabokov's oeuvre was recently accentuated in Insomniac Dreams: Experiments with Time by Vladimir Nabokov [21]. According to Nabokov, the otherworld stands as an alternative to reality, where the latter is also considered by the author exclusively from the irrational angle and enclosed in quotation marks: "Reality is a very subjective affair. I can only define it as a kind of gradual accumulation of information; and as a specialization... You can get nearer and nearer, so to speak, to reality; but you never get near enough because reality is an infi-

\footnotetext{
1 «романа в форме пьесы».

${ }^{2}$ Double-world [11], together with otherworld [12], dream reality [13], and irreality are the terms commonly used in Nabokov studies.
} 
nite succession of steps, levels of perception, false bottoms, and hence unquenchable, unattainable" [22].

Nabokov, both personally and indirectly, spoke about reality and the otherworld in his essay The Art of Literature and Commonsense [4]. The writer metaphorically offered his perception of reality and creative works, which he considered irrational by nature: "Two and two no longer make four, because it is no longer necessary for them to make four" [Ibid. P. 374]. Nabokov urged artists to give up the logic of common sense, which, according to his understanding, contradicts art and being in general, along with excluding immortality (the writer was especially sensitive to the latter). Thus, Nabokov questioned mathematical axioms. In his view, "one planet plus another" will not make two planets, as "the other planet may just as well turn out to be a double one" [Ibid. P. 375]. In other words, there are two levels, one of which is unnoticeable to the ordinary eye, otherworldly. Initially, Nabokov tried building the artistic world of his plays on the categories of reality, otherworld and dream. Later, this tendency shaped his novelistic oeuvre.

In the last dramatic work of Nabokov, a screenplay Lolita, the action develops around three interconnected dreams of the main characters. These are the threads of the dream-seeing reality tossed up by the author - the dreams of Humbert, Lolita, and Charlotte [6. P. 14, 20]. The action here is developed, as well as in Nabokov's other plays, following dream logic [Ibid. P. 13]. Having settled down in Charlotte Haze's house, Humber Humbert experiences a dream, in which he, "a knight in full armor riding a black horse along a forest road. Three nymphets, one lame, are playing in a sun-shot glade. Nymphet Lolita runs toward Humbert, the Dark Knight, and promptly seats herself behind. His visor closes again. At a walking pace they ride deeper into the Enchanted Forest" [23. P. 45-46].

Humbert did not intend to understand the meaning of this dream, but it can be assumed that the three nymphets are lame Ginny McCoo, in whose house Humbert should have stayed if it has not been burnt at the beginning of the story, Phyllis Chatfield, Lolita's companion in indecencies in the camp $Q$, and Lolita herself. The Enchanted Forest from Humbert's dream sends out connotations to the hotel, "Enchanted Hunters", where Humbert stays with Lolita and where she mentions a sleeping pill, saying that "it's a love philter" [Ibid. P. 101]. In the restaurant of the same hotel, Humbert and Lolita closely look at a mural which "depicts enchanted hunters in various postures and states of enchantment amid a medley of animals, dryads, cypresses, and porticoes" [Ibid. P. 100]. The author of this mural, which Humbert calls "mythological scenes", is named Lewis Ruskin. That alludes to two English writers who were fond of their "young charges", Lewis Carroll and John Ruskin [6. P. 16].

Charlotte's dream right before her death foretells the tragedy and represents one of the interconnected threads of the literary work. Charlotte almost drowns in Ramsdale Lake (Humbert's unaccomplished plan) and recalls that she has seen Humbert in her dream, when he offered her a pill or potion. Meanwhile, somebody's voice warned her: "Careful, Isolda, that's poison" [23. P. 83]. That 
is how Nabokov compares Charlotte with Isolde, who has mistakenly taken a love potion and bound herself with Tristan for life [6. P. 18]. The faulty relationship of Charlotte and Humbert indirectly causes her death. Meanwhile, the sleeping pill is taken by her daughter Lolita, who, while paying attention to the mirroring of a hotel room number and her home address (342), and not knowing about her mother's death, mentions that last night she dreamt "mother drowned in Ramsdale Lake" [23. P. 98].

All three dreams of the main characters shape the outcome of Humbert's tragedy and harbinger a special warning, which Humbert consistently ignores. Later, the structure of this dream becomes the basis for Humbert's and Lolita's trans-American trip, driven by dream logic, from one imaginary shelter to another, each even less real than the previous one, until Humbert loses Lolita. That loss is the fatal climax of his feelings that exceed the limits of common sense. Humbert's passion for Lolita entrances him, and Nabokov hints at this by bringing up Clare Quilty's play. The play Enchanted Hunters (a symbolic title which is mentioned throughout the screenplay) is staged in Beardsley College for girls, and Lolita acts there under the direction of Quilty: "The play is a charming fantasy. Several hunters are lost in a wood, and a strange girl they meet puts them into a kind of trance. They fraternize with mythical creatures. Of course, later the girl turns out to be a student at a nearby Institute for ExtraSensorial Studies" [Ibid. P. 143-144].

The author of the play, Quilty, who fools Humbert, is accompanied by his assistant Vivian Darkbloom (the anagram of Nabokov's name which was used earlier in the play The Wanderers), who together with Quilty is reminiscent of characters from another Nabokov's play [24] — Salvator Waltz and his assistant Trance ${ }^{1}$, the role of which is given to a woman, who is more a shadow than a real assistant.

Thus, in the screenplay of Lolita, the course of action develops based on dreams, according to Nabokov's favourite model - the logic of dream, or, as he explained in a foreword to the screenplay, "from motel to motel, mirage to mirage, nightmare to nightmare" [9. P. 10]. Nabokov's genre of 'dream tragedies', which specifies such plays as Shakespeare's King Lear and Hamlet and Gogol's Government Inspector, applies to his own works, including the screenplay of Lolita, which is entirely driven by the "logic of dream".

\subsection{Lolita as an Opposition to Poshlust in Art}

Throughout his life Nabokov developed his conception of 'veritable' art, which is opposed to platitudes, vulgarity, triviality, and philistinism, as reflected in popular culture, and called poshlust, poshlost', poshlism (variations of transliteration from the Russian language). In Lectures on Russian Literature, based

\footnotetext{
${ }^{1}$ In the original Russian version of the play The Waltz Invention, Trance is named Dream $(\mathrm{COH})$ in precise translation into English [25]. In that version he also belongs to the masculine gender.
} 
on his course materials for students of Wellesley and Cornell, Nabokov claimed that "Russians have, or had, a special name for smug philistinism - poshlust. Poshlism is not only the obviously trashy but mainly the falsely important, the falsely beautiful, the falsely clever, the falsely attractive" [26. P. 193].

The movement against poshlust in tsarist and Soviet Russia had been going seriously for more than a century: "Poshlost' is the Russian version of banality, with a characteristic national flavoring of metaphysics and high morality, and a peculiar conjunction of the sexual and the spiritual. This one word encompasses triviality, vulgarity, sexual promiscuity, and a lack of spirituality. The war against poshlost' was a cultural obsession of the Russian and Soviet intelligentsia from the 1860 s to 1960 s" [27. P. 41].

In his work Nikolai Gogol, Nabokov explained to foreign readers the meaning of the transliterated word poshlust, referred to "a certain widespread defect for which the other three European languages... possess no special term" [28. P. 63]. Nabokov insisted on the existence of the notion, notwithstanding the absence of an exact equivalent in the European languages spoken by him. His definition of poshlust in English includes "cheap, sham, common, smutty, pinkand-blue, high falutin', in bad taste", "inferior, sorry, trashy, scurvy, tawdry, gimcrack", added to "certain false values" [Ibid. P. 64]. Nabokov, the thinker and interpreter, expressed his conception the following way: "Poshlust - which renders in a somewhat more adequate manner the dull sound of the second, neutral ' $o$ '. Inversely, the first ' $o$ ' is as big as the plop of an elephant falling into a muddy pond and as round as the bosom of a bathing beauty on a German picture postcard" [Ibid. P. 63].

Nabokov repeatedly opined that, more than any other art form, literature is a reservoir of 'vulgar' views. When reviewing a new popular literary work, Nabokov never missed the opportunity to analyze all the praising comments and articles, which told nothing about the bestseller, other than, as Nabokov noticed, the astronomical sales figures of the book and contained loud empty epithets. The writer considered poshlust especially harmful, "vigorous and vicious when the sham is not obvious and when the values it mimics are considered, rightly or wrongly, to belong to the very highest level of art, thought or emotion" [Ibid. P. 68].

Nabokov insisted that art is not a pitiful reflection of life, but a reconstruction of reality, that frequently life can succeed art, and not vice versa: "The cult of self-containment of art as a special reality, which lives in conformity with the laws of its nature, inviolable laws of artistic fiction, was always characteristic of Nabokov the artist" [29. P. 39]. Nabokov had advocated this artistic attitude towards reality throughout his creative life. For Nabokov, the art of writing was an absolutely useless activity if it did not allow an understanding of the world as a fiction storehouse, to which an artist goes firstly to gather details, and then to unite them into a new harmonious world - in a reality created by himself

\footnotetext{
1 «Для Набокова-художника всегда был характерен культ самодостаточности искусства как особой реальности, живущей по законам собственной природы, по непреложным законам художественного вымысла».
} 
[4. P. 377]. Nabokov valued the art of the game, not of great ideas. He also could not stand any kind of moralization in the work of art. He said: "A writer is lost when he grows interested in such questions as 'what is art?' and 'what is an ar-tist's duty?" [26. P. 39]. These questions, in Nabokov's view, disturbed Nikolai Gogol during his work on the second volume of Dead Souls, which built the basis of the creative crisis of Gogol the genius. That is why Lolita the novel, as well as Lolita the screenplay, and the other works by Nabokov lack even a slight shadow of moralization and "didactic medicine". Nabokov expressed his irony through the screenplay's main narrator Dr. Ray's calling Humbert "horrible", "abject", "a shining example of moral leprosy", who "wrestled with strange wretched urges and kept searching for the child of his shameful obsession", but immediately thereafter contradictorily highlighted Humbert's pitiful tenderness and tragedy of this man looking for "some incarnation of his boyhood sweetheart" [23. P. 3, 9]. This raises the work, together with its subject, above philistine moral judgment to the upper level - aesthetics.

The high aesthetic value of the screenplay of Lolita, in its opposition to poshlust, can be examined further. Despite the fact that the screenplay was commissioned by Hollywood producers, it does not have anything in common with the 'popular art', which Nabokov had derided all his life [6. P. 10]. In the screenplay of Lolita, the difference between 'veritable' art and poshlust is primarily presented through the opposition of two characters - Humbert and Quilty. The connection between Humbert and Quilty is primarily studied in works on the novel Lolita [12, 17, 30]. Humbert Humbert, a writer and lecturer, delicate artist, aesthete and romanticist is opposed to another nymphet-lover, Clare Quilty, a popular playwright, who enjoys making pornographic movies with kids in his free time. This is how he is described in the author's stage direction: "Quilty is a tremendously successful phony, fortyish, roguish, baldish, with an obscene little mustache and a breezy manner which some find insulting and others just love" [23. P. 56]. To those who remark that Humbert is not a person of high morals, either, which is almost a curse for a common artist who produces 'veritable' art products, we can respond with Dr. Ray's words that "there are in his story depths of passion and suffering, patterns of tenderness and distress, that cannot be dismissed by his judges", which complies with Nabokov's postulates about 'veritable' art and beauty [Ibid. P. 3]. Moreover, Humbert's image can be defended with the last scene of the screenplay, when Humbert appears not as a mere madman, obsessed with irresistible and perverse passion, but also as a tender loving person ready to accept his beloved one, who has lost her nymphet look - "this Lolita, pale and polluted, and big with another's child" - and wait for her to come back as long as needed, if only she were to give him a microscopic hope [Ibid. P. 209].

Unlike Humbert, "the panting maniac" Quilty [Ibid. P. 3] is an absolute poshlyak. The term, derived from the abovementioned poshlust, is used to name its propagators. Even his manner of communication, with his ambiguous hints and sweet jokes, provoke antipathy. Meanwhile, his art, the products of which are shown on TV and staged at school, are conclusive evidence of his vulgarity. 
In Quilty's play Enchanted Hunters Lolita performs the main role, a student in a so-called Institute for Extra-Sensorial Studies [Ibid. P. 129]. His play The Nymphet fascinates Charlotte and Lolita [23. P. 57]. Neither play has any aesthetic or ethical value. This judgment is consolidated, when the corrupt tastes of both Lolita and her mother, and the sugary popularity of the playwright, are taken into account. The way Quilty abducts Lolita, uses her for his sordid pseudo-aesthetic purposes, and then gets rid of her as if she were a waste product, is juxtaposed with the delicacy of Humbert's suffering and the poetry of his feelings.

\subsection{The Play within the Play}

In the screenplay, we can also see a fundamental device of Nabokov's poetics - 'theatre within the theatre' - which is sketched in the novel Lolita and enhanced in the 'novel within the play' or Lolita screenplay up to the 'cubed theatre within the theatre'. Structurally, the screenplay is the "novel within the play', but it is also a multiple 'play within the play,' built on the basis of the nesting doll, with its hierarchic organization, on the highest level of which there is a principle director - the author. The screenplay of Lolita contains several 'plays within the play'. The core one is Nabokov's play, inside of which there is another, inner play, staged by Humbert's antagonist Clare Quilty, a pseudoartist, who has abducted Lolita and broken her heart. Besides that, Quilty stages two plays simultaneously: he directs the first one in Beardsley College, while staging the second one in Humbert's and Lolita's lives. In both plays, Lolita is the one who acts. She also uses the school play rehearsals as an excuse to meet Quilty in her real play, which has later become the fatal one for deceived Humbert. Thus, Clare Quilty is represented in the screenplay as a stage director of the 'play within the play within Nabokov's play', as well as a ghostly hero of Humbert's nightmares and a fairy clown for the audience (just have a look at his peacockery and sugary speech!). Charlotte Haze, along with the other characters, mentions Quilty's recent play Nymphets (this play briefly appears in the screenplay four times) and finds it pleasant to watch [Ibidem]. Perhaps, this is an allusion to the main play - the play of Humbert's life and his tragic love for Lolita.

Quilty appears throughout the whole screenplay - first here, then there. In one scene, he is wholly admired. In another one - Charlotte seems to be Quilty's old, casual acquaintance. In the third one - Charlotte suggests Humbert asks for help from his uncle, also named Quilty, upon which, Humbert, worried about Lolita's departure to the summer camp, excuses his bad mood with a toothache. It turns out that in the very beginning of the first scene Lolita is registered for an appointment with a dentist of the same name - Quilty. Later Quilty expresses himself in a magazine cover, which is tacked onto the wall in Lolita's room: "I can write without a pen, but not without a Drome"1 [Ibid. P. 72]. Quilty meets Charlotte in Lolita's college and excuses his leave with "a

\footnotetext{
${ }^{1}$ Drome is a cigarette brand, which at the same time implies drōm, meaning dream in Old Saxon.
} 
play of mine in Parkington" - another 'play within a play', momentarily passing by [Ibid. P. 57]. In her turn, Charlotte throws another ambiguous cue about one more of Quilty's plays within the main one: "Recently we had the pleasure of enjoying your Nymphet on Channel 5" [23]. Quilty also sends Lolita a bouquet of gorgeous roses (earlier, not by chance, a playwright rhymes name Dolores with tears and roses), spies on Lolita and Humbert in the hotel "Enchanted Hunters", and asks the latter private questions about his girl.

In the next scene, Quilty appears together with his companion Vivian Darkbloom (an assistant of the stage director producing several "plays within the play' at the same time), who is introduced by him as his "collaborator", "evening shadow", "a real woman - or anyway a real person" [Ibid. P. 146]. Here Nabokov, insisting on the real nature of this personage, insinuated the reverse. Vivian's niece Mona, as if instructed by the main stage director, helps Lolita to deceive Humbert and secretly meet Quilty. During an unseen telephone conversation, Quilty's offstage voice, laughing, warns Humbert about Lolita's abduction from the hospital [Ibid. P. 184-185]. Quilty is "a bold laughing cynic", as Lolita describes him and continues, "[the] only man I was ever crazy about" [Ibid. P. 205].

It appears that Humbert and Lolita act in the play made up by Quilty, who, as a matter of duty, has staged performances before. In Lolita's school, he stages a camouflaging play which allows him to meet Lolita conveniently and trick Humbert, who later kills the playwright. Nabokov's external play demonstrates itself through Dr. Ray's character, who kept the autobiography "which Mr. Humbert Humbert wrote after his arrest, in prison, where he was held without bail on a charge of murder, and in the psychopathic ward where he was committed for observation" [Ibid. P. 3]. Dr. Ray, who is, according to the stage direction, "a psychiatrist, perusing a manuscript on his desk" [Ibid. P. 2], appears on the highest level of authorship, second only to the screenplay's creator, as all the 'plays within the play', mentioned above, are contained within his own story about Humbert and his tragedy. This story is written by Humbert in the form of autobiography and handed in to Dr. Ray. Moreover, Humbert's memoirs are represented to a reader/spectator only after the death of the author (Humbert dies in prison); thus, here we encounter the narrator posthumously.

\subsection{Striving for Narration}

The genre of a literary screenplay appears as the most congenial for Nabokov the playwright as it presumes the presence of descriptive parts (screen prose), which are usually lengthier and more detailed than stage directions in a traditional play. For Nabokov, narration was an inherent attribute of the creative work. Yet there was not enough space within the form of a play to depict the scenes in a way that would satisfactorily represent the author's narrative intentions to an audience. On the other hand, the use of descriptive parts and offstage voices let Nabokov enhance the author's presence. Nabokov's interest in an au- 
thor's absolute power led him to explore the genre of a literary screenplay even before Lolita, in his work on The Tragedy of Mr. Morn. That is how we can explain the creation of multipage prosaic parts: "Narration [of the Tragedy]"1, with the detailed description of decorations, sound effects, characters' moods, as well as individually drawn "Character Lines"2 and "Development of Individual Character Lines"3 [32]. Gennady Barabtarlo names "Description of the Tragedy" as "a screenplay in prose", and this screenplay "is the author-stage-director's colossal remark, which can be unbuttoned from the play and read as a sample of excellent prose" ${ }^{4}$ [15. P. 282]. Responding to the expected question about Nabokov's rationale for expansive narration in his dramatic works, the following can be assumed. Traditionally, each dramatic work is predestined to be staged. Nabokov, aware that a collective creative staging of his work would inevitably distort the authorial ideas embodied in the plays, strove to "grant words primacy over action, thus limiting as much as possible the intrusion of management and cast" [9. P. 10].

In the Foreword to the Lolita screenplay, Nabokov put forth a cutting remark: "By nature I am no dramatist; I am not even a hack scenarist" [Ibid. P. 9]. He continued this train of thought, explaining that if he could devote the same time to the stage or cinematograph as he had given to the art of writing, he would make sure that everything - from acting to decorations - was saturated with the art and will of himself. Nabokov believed that the author should not tolerate a collective creative work, denigrating it as a "communal bath", in which each participant increases "a multiplication of mediocrity" [Ibid. P. 10]. The screenplay of Lolita, in particular, embodies Nabokov's idea of the author's absolute power. The writer recoursed to various narrative devices, which stamp the work with authorial power. These are lengthy author's stage directions, multiple descriptive parts, which grant the reader access to peculiarities of the operation of hotel water closets, parallel morning scenes taken from lives of individual hotel guests, mountain road scenes, sold goods in shop-windows of small roadside shops, and hospital life scenes. The range of devices is also enriched by inclusions of the whole insets from the novel, which, enclosed in quotes, tell about the tragic nature of Humbert's sufferings.

One of the most touching scenes of the novel is Humbert's self-talk during his last meeting with Lolita, which is generously provided in the screenplay in quotation marks: "I knew all I wanted to know. I had no intention of torturing my darling. Somewhere, beyond the shack, an afterwork radio had begun singing of folly and fate, and there she was with her ruined looks, and her adult ropeveined hands, there she was, my Lolita, hopelessly worn at seventeen - and

1 «Изложение».

2 «Линии персонажей».

3 «Развитие линий отдельных персонажей». These essential narrative parts of The Tragedy of Mr. Morn have been neither published in English nor included in the most recent translation of The Tragedy of Mr. Morn by A. Tolstoy \& T. Kharshan [31].

${ }^{4}$ «представляет собою огромную сценическую ремарку автора-режиссера, которая может быть отстегнута от пьесы и читаться как образец отличной прозы». 
I looked and looked, and knew that I loved her more than anything I had ever seen, or imagined, or hoped for... She was only dead-leaf echo of my nymphet - but thank God it was not that echo alone I worshipped. I loved my Lolita, this Lolita, pale and polluted, and big with another's child, but still gray-eyed, still sooty-lashed, still auburn and almond, still Carmencita, still mine. 'Changeons de vie ma Carmen, allons vivre quelque part où nous ne serons jamais séparés' [this is a quotation from Mérimée's novel] ${ }^{1}$, no matter, even if those eyes of hers would fade to myopic fish, and her nipples swell and crack - even then I would go mad with tenderness at the mere sight of your dear worn face, at the mere sound of your raucous young voice, my Lolita" [23. P. 208-209].

\subsection{The Enhanced Author's Presence and Hidden Messages}

The only driving force in the screenplay of Lolita, except for its dream logic, is the will of the author, who presents himself everywhere and in everything: in multiple lengthy explanations and descriptive insertions, in personages who direct a stage performance or comment on the entire act and its separate scenes (psychiatrist John Ray, doctor Braddock, Instructor, Quilty, Vivian Darkbloom, entomologist Vladimir Nabokov), and in the offstage voices of characters that remain unseen by the audience.

Except for narrative devices, which are realized in descriptions, the author's presence is accomplished by introduction of the author's 'envoys' directing, as is typical in Nabokov's writings, their own 'play within the play' or 'theatre within the theatre': Dr. Braddock, Quilty, his companion Vivian Darkbloom and entomologist Vladimir Nabokov [6. P. 21]. Another 'envoy', though more 'parenthetical' than the others, is the character of the Instructor, who explains to the audience and "a bunch of policemen" the scene of Charlotte's death depicted on the photo [23. P. 87]. His description of the road accident is close to Gogol's Mute Scene in The Government Inspector and parallels the revelation scene in Nabokov's play The Event.

In The Government Inspector: "The Mayor stands in the middle like a pillar, arms outstretched and head thrown back. On his right are his wife and daughter, straining to reach him. Behind him the Postmaster, transformed into a question mark, stands facing the audience. Behind him is the Inspector of Schools in a state of innocent bewilderment. Behind him, right at the edge of the stage, are three ladies leaning against each other, directing the most sarcastic looks at the mayor's family. To the left of the Mayor stands the Warden of Charities, his head is slightly cocked to one side, as if he were listening for something. Behind him is the Judge, arms spread wide, squatting almost to the floor and puckering his lips as if about to whistle or mutter: 'Now we are really in the cart!' Behind him is Korobkin, winking towards the audience and directing contemptuous looks at the Mayor. Behind him, right at the edge of the stage, stand Bobchinsky and Dobchinsky, arms

\footnotetext{
${ }^{1}$ The author's remark.
} 
outstretched towards each other, mouths gaping, eyes popping. The other guests are simply transformed into pillars. The petrified group maintains this position for about a minute and a half. [Curtain]" [33. P. 306].

It invites comparisons with Troshcheykin's monologue directed at his wife Lyubov in The Event, (the play's sole life-assessing speech): “...Alone on this narrow, lighted stage. Behind us, the old theatrical frippery of our whole life, the frozen masks of a second-rate comedy, and in front a dark chasm full of eyes, eyes, eyes watching us, awaiting our destruction" [5. P. 214].

Compare how the Instructor explains the scene of Charlotte's death in the screenplay of Lolita: "Now, this is the picture of a real accident. To the ordinary spectator who has just arrived on the scene the situation may seem very, very unusual: it is not so, really. The lap robe there, on the sidewalk, covers a dead woman. The elderly person here on the grass is not dead but comfortably recovering from a mild heart attack. His nephew, the fat fellow talking to the police officers, was driving him to a birthday party when they ran over this woman. This is their car up on the slope of the lawn where it came to rest after leaving the road. It was moving down the street like so... The driver was trying to avoid the dog. The woman was crossing here. She was in a great hurry to mail a letter but never made it to the mailbox. (still picture again) ${ }^{1}$. That man there who stands looking stunned is her husband. The still comes to life. A little girl picks up the letter which Charlotte was about to post and hands it to Humbert. Old Mr. Jung ${ }^{2}$ is sobbing uncontrollably. The ambulance arrives. The Farlows lead Humbert away" [23. P. 87-88].

Gogol's Mute Scene is usually understood as a scene of the enhanced condemnation of bureaucracy and institutionalized pretence. But on the higher level of interpretation, it is also a way out to the transcendental with its implied supernatural power, which may judge the characters by their real merits. It is a reminder about the Judgment Day for all of us. In The Event, the revelation scene bears the same connotations - as a serious self-assessment of the artist's fake achievements - in both the creative and personal life. In the screenplay of Lolita, the explained picture of Charlotte's death, notwithstanding its comical elements, is a hint at Humbert's responsibility for Charlotte's death, as well as for the tragedy of his and Lolita's lives. Here the Inspector acquires the attributes of that supernatural power, observing Humbert and the people affected by his obsessive passion in action.

From the perspective of the author's presence in the Lolita screenplay, a comparative analysis of the screenplay and the novel uncovers the transformation of some characters. Clare Quilty appears in the screenplay as a director of a 'play within Nabokov's play', a ghost hooting after Humbert, and as a fair clown at the same time, which is symbolic. Mister Coo, as he is called by his acquaintances, also hides himself behind his name, as 'cue' means not only a

\footnotetext{
${ }^{1}$ The author's remark.

${ }^{2}$ This can be considered as Nabokov's allusion to a psychiatrist and psychoanalyst Carl Gustav Jung.
} 
'stage remark', but also a 'hint' and 'stage direction' [6. P. 21]. Doctor Ray in the screenplay, compared to John Ray, the 'author' of a so-called foreword to the novel Lolita, which is not as much a foreword as an inseparable part of the novel in terms of composition and meaning ('novel within the novel'), acquires a more significant meaning, functioning as an additional narrator and elucidator in the action itself.

Through Dr. Ray's Offstage Voice (in one case it is titled as Narrator's Voice with parenthetical specification "Dr. Ray's"), Nabokov primarily interacts with the implied reader. It tells about the tragic love of Humbert for Anabella, and his desire to revive his beloved one in an adolescent girl [23. P. 8-9]. Moreover, it informs the reader of Humbert's and Lolita's biographical paths [Ibid. P.10, 1215]. It also gives some directions to the reader: "Watch the cab" [Ibid. P. 11]. Dr. Ray's Offstage Voice translates characters' cues from French and evaluates characters' actions and emotional state on the stage in terms of theatrical performance: "She had never been so voluble" [Ibid. P. 11-12]. As a stage director, it foresees characters' actions, as if following preliminary deliberated plan or a screenplay: "I think the cab driver ought to have turned left here. Oh, well, he can take the next cross street" [Ibidem]. The Voice also gives hints as for the future tragedy: "When you analyze those jaywalkers you find they hesitate between the womb and the tomb" - hint for the tragic death of Charlotte Haze under the car wheel [Ibid. P. 13]. In one case, it even belongs to Humbert's doctor-psychiatrist [Ibid. P. 187-188].

Apart from those hero-envoys, the screenplay is packed with multiple offstage voices that provide allusions for the audience and explain things that cannot be understood from the dialogues. These are Dr. Ray's Voice, Humbert's Voice, Lolita's Voice, Quilty's Voice, Fruity Voice, and others. For example, Narrative Undervoice of the art collector, along with His Subdued Narrational Voice, tells how he has bought "a miniature statue: a tiny bronze nude" [Ibid. P. 129-130]. Meanwhile, an Old Man's Voice laughs and makes ambiguous assumptions in a conversation with Humbert [Ibid. P. 140-141]. In the last scene of the screenplay, Dr. Ray's Narrational Voice explains the finale of Humbert's and Lolita's story: "Poor Lolita died in childbed a few weeks later, giving birth to a stillborn girl, in Gray Star, a settlement in the remote Northwest. She never learnt Humbert finally tracked down Clare Quilty and killed him. Not did Humbert know of Lolita's death when shortly before his own dissolution he wrote in prison these last words of his tragic life's story" [Ibid. P. 212-213]. Nabokov used those characters 'from the author' and 'voices' to implement authorial unlimited presence, and as means of introducing an expansive narration that is usually limited in drama as a literary genre.

\footnotetext{
${ }^{1}$ According to the author's remark, he is a "psychiatrist" Dr. Ray, "who appears in the Prologue [which is a part of the screenplay], and will appear again at the very end of Act Three" [23. P. 187; emphasis added. - O.B.].
} 


\section{Conclusion}

The screenplay of Lolita not only contains all the major aesthetic and philosophical conceptions essential for a mature Nabokov-novelist, but also the artistic devices he elaborated upon as a playwright. It perfectly embodies Nabokov's genre of a dream-tragedy, the main attributes of which are the substitution of a plot as the driving force with the logic of dream and the opposition 'reality otherworld and dream'. The screenplay of Lolita is also a remarkable representation of Nabokov's views on 'veritable' art versus poshlust - the untranslatable notion, transliterated from the Russian language, meaning 'vulgarity', 'platitude', 'banality', 'commonness', 'triviality', 'kitsch', 'false values', and used in description of artworks which possess those characteristics. In the screenplay, poshlust is exposed via contradictory character-rivals both related to the art of literature and theatre - Humbert Humbert and Clare Quilty. The screenplay is built on the fundamental device of Nabokov's poetics, 'theatre within the theatre'. Akin to the intricacy of a nesting doll, Nabokov evoked the infinite 'play within the play within another play,' or the 'cubed theatre within the theatre'. Being a novelist by nature, Nabokov had an absolutely authoritative approach to drama as a literary work and stage performance, which explains his striving for narration even in dramatic works. The Lolita screenplay is, more than any other Nabokov's play, imbued with descriptions and lengthy stage directions, which also serve another artistic purpose: enhancing the author's presence within the text (again, a device much favoured by Nabokov). The idea of highlighting the author's presence also finds its realization through the introduction of the author's 'envoys', directing the course of action and indirectly conveying the author's messages. The artistic device of the 'cubed theatre within the theatre', with its multiple authors and stage directors in a multilayered theatrical structure (Quilty staging several plays, Humbert with his biography, Dr. Ray with his history about Humbert, and, finally, Nabokov with his screenplay) is used for the purpose of realizing the author's game with the implied reader/spectator. It positions the author's image at the forefront, and, to a greater degree, highlights Humbert Humbert's tragedy. It is also conducive to the embodiment of Nabokov's theory of the perfect play. Prior to the screenplay of Lolita, Nabokov had not written a single dramatic work of such a multilayered structure based on the 'theatre within the theatre'.

\section{References}

1. Nabokov, V.V. (1984) Playwriting. In: Nabokov, V.V. The Man from the USSR \& Other Plays (pp. 315-322). San Diego, New York and London: Harcourt Brace Jovanovich Publishers.

2. Nabokov, V. V. (1984) The Man from the USSR \& Other Plays. Translated from Russian by D. Nabokov. San Diego, New York and London: Harcourt Brace Jovanovich Publishers. pp. 323-342.

3. Babikov, A. (2008) Primechaniya [Commentaries]. In: Nabokov, V.V. Tragediya gospodina Morna. P'esy. Lektsii o drame [The tragedy of Mr. Morn: Plays. Lectures on drama]. St. Petersburg: Azbuka-klassika. 
4. Nabokov, V.V. (1980) The art of literature and commonsense. In: Bowers, F. (ed.) Lectures on literature. New York: Harcourt Brace Jovanovich/Bruccoli Clark.

5. Nabokov, V.V. (1984) The Man from the USSR \& Other Plays. Translated from Russian by D. Nabokov. San Diego, New York and London: Harcourt Brace Jovanovich Publishers. pp. 123-263. (Original work published 1938).

6. Babikov, A. (2010) Podrobnosti kartiny [Details of the picture]. In: Nabokov, V.V. Lolita: Stsenariy [Lolita: A screenplay] Translated from Russian by A. Babikov. St. Petersburg: Azbuka-klassika.

7. Harris, J.B. (producer) \& Kubrick, S. (director) (1962) Lolita [Motion Picture]. United States: A. A. Productions, Anya, Seven Arts Productions, Transworld Pictures.

8. Kassar, M. \& Michaels, J. B. (producers) \& Lyne, A. (director) (1997) Lolita [Motion Picture]. United States and France: Guild, Lolita Productions, Pathé.

9. Nabokov, V.V. (1997) Lolita: A screenplay. New York: Vintage International. pp. $7-$ 13. (Original work published 1974).

10. Nabokov, V.V. (2010) Lolita: Stsenariy [Lolita: A screenplay] Translated from Russian by A. Babikov. St. Petersburg: Azbuka-klassika.

11. Grishakova, M. (2006) The models of space, time and vision in V. Nabokov's fiction: Narrative strategies and cultural frames. Tartu: Tartu University Press.

12. Alexandrov, V.E. (1991) Nabokov's otherworld. Princeton: Princeton University Press.

13. Frank, S. (2012) Nabokov's theatrical imagination. Cambridge: Cambridge University Press.

14. Barabtarlo, G. (1993) Aerial Views: Essays on Nabokov's Art and Metaphysics. New York: Peter Lang.

15. Barabtarlo, G. (2011) Sochinenie Nabokova [Nabokov's oeuvre]. St. Petersburg: Ivan Limbakh Publishing House.

16. Boyd, B. (1990) Vladimir Nabokov: The Russian years. Princeton: Princeton University Press.

17. Boyd, B. (1991) Vladimir Nabokov: The American years. Princeton: Princeton University Press.

18. Senderovich, S.Y. \& Shvarts, Y.M. (2000) Poetika i etologiya Vladimira Nabokova (Predvaritel'nye tezisy) [Vladimir Nabokov's poetics and ethology (Preliminary theses)]. Nabokovskiy Vestnik. 5. pp. 19-36.

19. Babikov, A. (2001) Sobytie i samoe glavnoe v dramaticheskoy kontseptsii V.V. Nabokova [Event and the main thing in V.V. Nabokov's dramatic conception]. In: Averin, B.V. (ed.) V.V. Nabokov: pro et contra: materialy $i$ issledovaniya o zhizni i tvorchestve V.V. Nabokova: Antologiya [V.V. Nabokov: pro et contra: Materials and studies about life and creativity of V.V. Nabokov: Anthology]: in 2 vols. Vol. 2. St. Petersburg: Russian Christian Humanitarian Institute.

20. Babikov, A. (2008) Izobretenie teatra [Invention of the theatre]. In: Nabokov, V.V. Tragediya gospodina Morna. P'esi. Lektsii o drame [The tragedy of Mr. Morn: Plays. Lectures on drama]. St. Petersburg: Azbuka-klassika.

21. Barabtarlo, G. (ed.) (2018) Insomniac Dreams: Experiments with Time by Vladimir Nabokov. Princeton and Oxford: Princeton University Press.

22. Nabokov, V.V. (1962) Nabokov's interview for BBC Television (P. Duval-Smith, C. Burstall, Interviewers). [Online] Available from: http://lib.ru/NABOKOW/Inter02.txt (Accessed: 27.12.2017.

23. Nabokov, V.V. (1997) Lolita: A screenplay. New York: Vintage International. (Original work published 1974).

24. Nabokov, V.V. (1966) The Waltz Invention. Translated from Russian by D. Nabokov. New York: Phaedra. (Original work published 1938).

25. Nabokov, V.V. (2008) Izobretenie Valsa [The Waltz Invention]. In: Nabokov, V.V. Tragediya gospodina Morna. P'esy. Lektsii o drame [The tragedy of Mr. Morn: Plays. Lectures on drama]. St. Petersburg: Azbuka-klassika. 
26. Nabokov, V.V. (1981) Lectures on Russian literature. New York: Harcourt Brace Jovanovich/Bruccoli Clark.

27. Boym, S. (1994) Common places: Mythologies of everyday life in Russia. Cambridge: Harvard University Press.

28. Nabokov, V.V. (1961) Nikolai Gogol. New York: New Directions.

29. Shvabrin, S.A. (1999) Polemika Vladimira Nabokova i pisateley "Parizhskoy noty" [Polemics of Vladimir Nabokov and the writers of the "Parisian Note"]. Nabokovskiy Vestnik. 4. pp. 34-41.

30. Proffer, C.R. (1968) Keys to Lolita. Bloomington: Indiana University Press.

31. Nabokov, V.V. (2013) The Tragedy of Mr. Morn. Translated from Russian by A. Tolstoy \& T. Kharshan. New York: Random House LLC.

32. Nabokov, V.V. (2008) Prilozheniya [Appendices]. In: Nabokov, V.V. Tragediya gospodina Morna. P'esy. Lektsii o drame [The tragedy of Mr. Morn: Plays. Lectures on drama]. St. Petersburg: Azbuka-klassika.

33. Gogol, N. (2005) The Diary of a Madman, The Government Inspector and Selected Stories. Translated from Russian by R. Wilks. London: Penguin Books. pp. 211-306. (Original work published 1836).

\section{СОВЕРШЕННАЯ ПЬЕСА НАБОКОВА: СЦЕНАРИЙ «ЛОЛИТА» В СВЕТЕ АВ- ТОРСКИХ ВЗГЛЯДОВ НА ИСКУССТВО ДРАМАТУРГИИ}

О.А. Бабенко

Ключевые слова: Набоков, сценарий, театр, драматургия, пошлость, повествовательность.

В представленной статье последнее и самое малоизученное драматургическое произведение Набокова - сценарий по роману «Лолита» - исследуется с точки зрения теоретических взглядов писателя на предмет эстетически удовлетворительной пьесы. Анализируя произведения многих драматургов, Набоков размышлял о критериях совершенной пьесы, что отразилось в его литературно-критическом наследии. Цель исследования, проведённого преимущественно на материале сценария «Лолиты», - определить эстетическую значимость заключительного драматургического произведения Набокова в целом, а также по отношению к его теории совершенной пьесы. В исследовании использованы структурный, психологический и историко-функциональный методы, а также метод интертекстуального анализа и приёмы сравнительного литературоведения, что обусловлено мета-, интер- и гипертекстуальностью творчества Набокова.

Во Введении изложены взгляды Набокова на драму как литературный жанр и сценическое представление, а также рассмотрено его видение структурных элементов пьесы. Так, вместо логики детерминизма и конфликта как основной движущей силы пьесы Набоков предлагает свободу случая и логику сна. Автор статьи приходит к выводу о необходимости изучения сценария «Лолиты» с применением методологии Набокова.

В параграфе «"Лолита" как воплощение художественного инструментария Набоковадраматурга» сценарий исследуется с точки зрения соответствия набоковским критериям содержания и формы совершенной пьесы. В параграфе «"Лолита" как трагедиясновидение» на основе анализа сценария «Лолиты» по отношению к основополагающей концепции творчества Набокова - двоемирия - делается вывод, что сценарий, следуя терминологии самого Набокова, жанрово относится к трагедии-сновидению и является воплощением набоковского идеала о таковой. В параграфе «“Лолита” как оппозиция пошлости в искусстве» рассматривается понятие пошлости, его значение в русской культуре и творчестве Набокова. Оппозиция истинного искусства и пошлости обнаруживается и изучается по линии Гумберт Гумберт - Клэр Куильти. Параграф «Пьеса в пьесе» посвящён фундаментальному приёму набоковской поэтики - «театру в театре». В ходе анализа делается вывод, что в сценарии этот приём является структурополагающим и доведён до такой степени иерархической организации, что произведение представляет собой 
многоуровневую «пьесу в пьесе». В параграфе «Стремление к повествованию» описываются набоковские приёмы по расширению повествовательного пространства в драме. Сценарий «Лолиты» определяется как пример самой успешной реализации этих приёмов. В параграфе «Усиленное авторское присутствие и скрытые смыслы» изучаются способы выражения авторского присутствия.

Автор статьи заключает, что в сценарии в полной мере реализованы основные концепции и приёмы индивидуального творческого инструментария Набокова: сновидческая логика развития действия; многоуровневая структура пьесы на основе «театра в театре»; оппозиция между «настоящим» искусством и пошлостью; расширенное повествование, реализующееся посредством прозаических вставок из романа «Лолита», внесценических рассказчиков, внутритекстовых персонажей-режиссёров и распространённых авторских ремарок; усиленное авторское присутствие с многочисленными «авторами»; одновременное исполнение персонажами нескольких ролей и раскрытие автором своих приёмов в игре с читателем. Таким образом, сценарий «Лолиты» представляет собой не только эстетически удовлетворительную пьесу, но и воплощение драматургических исканий Набокова. 